\title{
Influence of flushing and other characteristics of coastal lagoons using data from Ghana
}

\author{
Steve Mitchell ${ }^{1}$, Isaac Boateng ${ }^{2}$, Fay Couceiro ${ }^{3}$ \\ ${ }^{1}$ Senior Lecturer \\ ${ }^{2}$ Senior Lecturer \\ ${ }^{3}$ Research Fellow \\ School of Civil Engineering and Surveying, Portland Building, University of Portsmouth PO1 3AH, UK \\ Corresponding Author: Steve.Mitchell@Port.ac.uk
}

\begin{abstract}
The challenges associated with managing systems of shallow coastal lagoons along a rapidly evolving coastline are illustrated in a case study of small lagoon systems in Ghana where these important structures are relied on by a range of different stakeholders for a variety of different purposes including fishing, tourism and salt production. Results of some water quality measurements are presented, showing that these lagoons have poor ecological status where they experience either a lack of flushing by the tide, or large amounts of anthropogenic inputs, or both. A vulnerability assessment is applied to the lagoons in question and this reveals a varying degree of threat from climate change to the operation and use of the lagoons. Our understanding of these systems suggests that a set of 1D hydrodynamic models, underpinned by an understanding of the local coastal sediment transport in each case, is appropriate, and could then be used to inform stakeholders and management in decision making. Integrated, broad-ranging management strategies must adapt to the realities of climate change in order to allow the sustainable use of these lagoons in providing economic benefits, ecosystem services, and elements of coastline protection for the benefit of the local and regional population and its economy.
\end{abstract}

\section{Keywords}

Coastal Lagoons; Flushing; Vulnerability; Ghana 


\subsection{Introduction}

Many coastal regions of the world contain lagoon-like structures where shallow water bodies are protected by barriers consisting of beach material. These lagoons have generally formed due to the influx of fresh water from the land, which can either escape seawards or become trapped in the lagoon, depending on the magnitude of the flow, the tidal state, and the width and cill level of the barrier. The barrier is itself controlled by the magnitude of the fresh water flow and by the nature of the coastal processes, particularly wave action, causing longshore drift or some other means of transport of beach material, which then restricts the flow of water between the sea and the lagoon, or can stop it altogether.

Many authors have contributed to our mechanistic understanding of coastal lagoon processes in general terms (e.g., Conesa \& Jiménez-Cárceles, 2007; Kjerfve, 1994). Worldwide, lagoons are important for fisheries, protection from storms, washing/bathing, amenity, tourism, as well as other industries and ecosystem services. Local industries in particular may benefit from a water body that is at least partly sheltered from winds and storm events, thus providing a source of income for local people. Understanding the factors that control the level of different kinds of pollution that arise is therefore of enormous benefit to all stakeholders (Roselli et al., 2013).

Coastal lagoons are under continual threat due to climate change because they are lowlying, exposed, and generally subject to continual erosion and deposition; in most cases, however, it is not clear to what extent any of the processes associated with climate change could affect the operation of the lagoon in question for those who most wish to make use of it (Chapman 2012, Gaertner-Mazouni \& de Wit, 2012, Brito et al, 2012). Where the lagoon is being used as a nature reserve, for example (Mitchell et al, 2008), it may well be that any local sea level rise simply adds to the availability of sediment, which then gives rise to the establishment of new salt marsh areas, of benefit to a range of species. On the other hand, it is clear that issues of climate change can only be addressed provided that consistent and tested governance strategies are applied in consultation with stakeholders (La Jeunesse et al, 2015). Several authors have made some mention of the importance of using reliable and tested numerical models to predict likely outcomes in years to come.

A large body of literature from around the world is a testament to the appeal of research work that seeks to understand the hydrodynamics and response of such systems to coastal processes and anthropogenic change. Broadly, recent studies can be categorised into three main areas. First, a number of authors have addressed the role of morphodynamics on the changes to the hydraulic regime. This is perhaps most relevant to the present study. Of key interest are the tidal range, fresh water input, and the supply of sediment. It is this balance of processes (Moreno et al, 2010; Duck \& Figueiredo da Silva, 2012; Ozturk \& Sezli, 2015) that generally determines the fundamental tendency of the lagoon to be flushed by the tide. In this vein, the wellknown categorisation of Kjerfve (1986) has helped to forge a better understanding of the 
different types of lagoons and how these respond over different time scales to different hydrological and geomorphological processes. Second, of interest to many researchers are the fundamental processes connected with the hydrodynamics and related water quality within the lagoon (Jewell et al., 2012; Dussaillant et al., 2009; Serrano et al., 2013). In deeper lagoons vertical density stratification can also be a consideration in the trapping or release of chemical species in deeper waters (Albarakati \& Ahmad, 2012). Third, many researchers relate the importance of groundwater or through-barrier flow and the effect this has on the chemistry and water quality of the lagoon (Chikita et al, 2012; Stieglitz et al., 2013; Austin et al., 2013). Table 1 shows the geographical distribution of a selection of recently published studies that have informed previous debates about the local management of lagoon systems, and have helped our understanding of lagoon management generally. This list is not exhaustive but it nevertheless provides a sense of the recent diversity of interest in lagoons; the literature perhaps above all illustrates the diversity of different lagoon types, uses, threats, and opportunities.

The management of coastal lagoons is often governed by a multitude of considerations related to morphodynamics, hydrodynamics, water quality and ecology, all of which requires a multidisciplinary approach to a complex and rapidly changing problem. Few studies to date have considered the interaction between the physical processes that control their shape and depth, for example, and the chemical and biological interactions that control the usefulness and the economic and social value of the lagoon, for example. This is important because it is those who rely on the lagoon who most feel the effects of any change that takes place, and they themselves may or may not have a good understanding of the causes and mechanisms involved in the change. As in all such cases it is only by making management decisions based on real scientific understanding of specific systems that long term sustainable decisions can be made.

The practicalities and expense of undertaking fieldwork means that some coastal lagoon systems have received more attention than others; West African lagoons, for example, are relatively poorly understood in terms of their morphology and general ecological status. The aim of this article is to report the levels of pollution in some small coastal lagoons using case studies of lagoons in Ghana, West Africa, in relation to their state in terms of water exchanges and the degree of protection or closure from the sea. We also undertake an assessment of the present threats via a vulnerability analysis, and consider what sort of model might be best suited to the lagoons in question, with a view to making comments about the likely system response to global climate change, in terms of rising sea levels or increased severity and incidence of storms. 


\subsection{Coastal Lagoons in Ghana}

\subsection{Background}

Despite the wide body of literature on coastal lagoons, relatively little of it relates to developing economies where subsistence-type farming or fishing may be important. Furthermore, the lack of consistent development or coordinated construction activities away from the main urban centres has precluded the detailed investigation of the coast of West Africa as a whole, or its response to the main processes that affect all coasts. Ghana's population was estimated at 27.9 million in 2015, up from the 24 million recorded in the 2010 National Population and Housing Census (Ghana Statistical Services, 2015). The country covers a total land area of $238,533 \mathrm{~km}^{2}$ and has $540 \mathrm{~km}$ of coastline. The coastal zone of Ghana, defined as the area below the $30 \mathrm{~m}$ contour, represents about $7 \%$ of the land area (Boateng, 2009) and has about 50 coastal lagoons interspersed along the shoreline. Very little is known about many of these lagoons, though the few that have been studied (Entsua-Mensa, 2002; Entsua-Mensah et al, 2000) suggest that they provide valuable ecosystem services that support not only the wildlife and fauna, but also the subsistence economy of the rural coastal dwellers and the entire economy of Ghana.

Lagoons in Ghana provide valuable resources such as fish and crabs for sale and local consumption by fishermen. Reeds and other plants are cut for thatch and for weaving mats for sale at markets both near the lagoons and further afield. In some areas, vegetables are grown in sandy garden beds irrigated with water drawn by hand from wells along the edges of the lagoons and mangrove swamps of Ghana's coastline. Salt evaporation ponds are created along the banks of some salty lagoons (e.g., Nyanya Lagoon; Figure 1 and Table 2) for the commercial production of salt by local people. In fact, lagoons are among Ghana's most valuable ecosystems because they are closely tied to salt marshes, mangrove swamps, and tidal flats, all of which constitute significant features of Ghana's coastline providing critical habitats for many fish and wildlife resources supporting the economy.

However, these coastal lagoons are highly fragile and vulnerable to both natural processes and anthropogenic activities. Urbanisation and land-based pollution mostly have significant impacts on the water quality, hydrodynamics, geomorphology and the biodiversity of coastal lagoons and these significantly affect the natural processes and ecosystem services provided by lagoons. Similarly, coastal lagoons in Ghana suffer from land-based pollution (domestic, industrial and agriculture), which weaken not only their ability to produce the natural services, but their resilience and their capacities to mitigate and adapt to Climate Change (IPCC, 2014). 


\subsection{Impacts of Climate Change}

The effects of Climate Change (particularly increased temperatures, sea level rise, increase intensity of storms and high precipitation) could cause changes to the geomorphology, hydrodynamics and sediment flows into coastal lagoons. The effect of sea level rise is of particular concern as identified by Carrasco et al (2015), who pointed to a pressing need for further research on this issue. These factors as a whole could disrupt the productivity of the ecosystem services of the lagoons and potentially jeopardise the livelihoods of coastal communities that subsist on the lagoon resources. The extent and intensity to which the impacts of Climate Change affect coastal lagoons depend on local and regional climatic and environmental conditions as well as on the anthropogenic stressors, mitigation and adaptation policies in place. There is a need to conduct investigations into the impacts of Climate Change on coastal lagoons at a local scale. As part of a pilot study, this paper contains a report of preliminary attempts to investigate Ghana's coastal lagoons to ascertain general impacts and identify key driving forces to enable the development of adaptation and mitigation strategies

\subsection{Lagoon Types}

There are two main types of coastal lagoons in Ghana (Boateng, 2009), namely 'open' and 'closed' (Figure 2). Open lagoons are permanently open to the sea and are normally fed by rivers that flow all year round. They occur mostly on the central and western parts of the coastline of Ghana where higher rainfall results in a more continuous flow of fresh water in the rivers and streams. Closed lagoons on the other hand are separated from the sea by sand barriers. They are more common on the eastern segments of the coastline where rainfall is low and highly seasonal. Some closed lagoons are open to the sea during the rainy season when floodwaters from the hinterland break the sand barrier. Storm surges may also erode sand barriers and open up closed lagoons to the sea. Under certain circumstances, the sandbar may be manually breached during the rainy season to allow flushing of the lagoon water to reduce the risk of flooding to adjacent settlements where this may be considered a threat.

This typology of lagoons can be related to the Kjerfve (1986) geomorphic classification of choked, restricted and leaky. Choked lagoons are open lagoons, with a narrow channel due to deposition occurring on one or both sides of the inlet. Restricted lagoons are closed lagoons as a result of barriers that restrict or limit tidal exchange. There are a few closed lagoons in Ghana which become leaky seasonally as a result of increased freshwater or higher tidal currents creating several openings across the elongated shore-parallel sandy barrier that confines the lagoon water. In most cases, the leaky channels do not last long because of strong west-to-east longshore drift. Constructive wave conditions close the leaks a few months after the barrier breaching forces (freshwater discharge/high tidal condition) have subsided. 


\subsection{Description of study area}

This study focuses on eight (8) selected coastal lagoons located between Tema (east of Accra) and Winneba (west of Accra) (see Figure 1). All the sampled lagoons were representative of the different types of lagoons in Ghana and are listed in Table 2 following a numerical order from east to west.

Compared with many other systems in different parts of the world the tidal range in Ghana is low and varies little between spring and neap tides (Table 3). Tidal currents are generally low and have relatively little influence on coastal processes except within tidal inlets. The coast of West Africa, including Ghana, experiences an increase in water levels of up to about $10 \mathrm{~m}$ due to upwelling and storm surge associated with the onshore movement of the Southwest monsoon winds, which occur between May and October (Wellens-Mensah et al, 2002). Another factor attributed to the upwelling along the coast of Ghana is the influence of the Guinea Current. Henin et al (1986) identified that the Guinea Current flows eastwards at approximately 3N along the western coast of Africa. It has at least two sources: the North Equatorial counter current and Canary Current. According to Bakun (1978) the Guinea Current, like other eastern ocean boundary currents, is characterised by areas of upwelling. The effects of climate change are expected to increase the intensity and impact of upwelling along the coast of Ghana.

Although data are somewhat scarce there is some limited information available on the magnitudes of fresh water flow for some catchments in Ghana (Water Resources Commission, 2009), and also on the associated sediment transport into the coastal zone (Akrasi, 2011). Fresh water flow is generally zero or near-zero in the dry season although during the rainy season large amounts of fresh water can reach the coastal zone over a range of different time scales. Different lagoons therefore tend to respond more or less rapidly in terms of their chemical and physical processes to the arrival of the rainy season. A typical lagoon of interest to this study is shallow, well mixed, and extends up to a distance of several $\mathrm{km}$ inland. Key controls on tidal and fluvial flushing include the lagoon area and depth, the magnitude of the fresh water flow, the tidal height and range relative to the cill level, and the width of the breach section. Beach sediment material is highly mobile on the exposed coast meaning that some lagoons can open and close regularly, while others are maintained as open structures because the sediment that arrives at the breach from longshore drift cannot become established and consolidated for sufficiently long to close the lagoon; in other words, the breach is self-scouring. 


\subsection{Study Sites and Methodology}

\subsection{Case study site selection}

An initial assessment and identification of the case study area was carried out in order to develop a general understanding of the characteristics of the coastal lagoons in Ghana. This involved a review of all relevant literature together with satellite images and historical maps of Ghana's coast. Through this assessment it was possible to identify a total of about fifty (50) coastal lagoons along the $540 \mathrm{~km}$ coastline.

Coastal lagoons between Tema and Winneba (Figure 1) were selected as case study areas because this area contains both open and closed, urban and rural lagoons and thus presented us with an opportunity to assess the impacts of both anthropogenic activities and climate change. Following the identification of the case study area, individual lagoons within the area were assessed and eight (8) of them were selected for sampling. This selection was based upon identifying a representative sample to cover open, closed as well as rural and urban lagoons.

Two field campaigns were conducted on the selected lagoons on 14-18 September 2015 (end of the rainy season) and 25-27 January 2016 (dry season) to allow observation of the seasonal variations in flow, pollution levels, and inlet morphodynamics. The sampling was undertaken extensively on all eight selected lagoons during the first field campaign in September 2015, but in January 2016 the campaign instead focused intensively on three lagoons in particular (Lagoons 2, 5, 7 in Table 2). All sampling took place in lagoons at around low water. The extensive (September 2015) sampling was an attempt to study the geomorphology and the climate change vulnerability, and to identify the general patterns of water quality as well as the levels of pollution in the eight selected lagoons.

The three intensively sampled (January 2016) lagoons were selected based on the outcome of the preliminary field work. The more intensive sampling also allowed these three lagoons to be sampled from the coastal zone to points that were further upstream than in the September campaign, in order to identify the distribution of pollution along the length of the lagoon channel.

\subsection{Measurements}

Water parameters, temperature, salinity, $\mathrm{pH}$, turbidity and dissolved oxygen, were measured in situ using a YSI Pro DSS multiparameter sonde. Salinity was measured using the practical salinity scale, and is hereafter quoted without units. Once in place the sonde logged data every 2 seconds for 30 seconds and the data were averaged 
over that time period. $500 \mathrm{ml}$ water samples were also taken and $100 \mathrm{ml}$ was filtered on site then stored in a cool box for subsequent nutrient analysis (maximum storage time 8 hours). The remaining $400 \mathrm{ml}$ was stored in the cool box unfiltered and used for microbial analysis on the evening of the same day. Nitrate, nitrite, ammonia and soluble reactive phosphorus were determined colourimetrically using Palintest photometer tablet reagents and the Palintest 7500 photometer. Tablet reagents were; Nitrate (Nitratest ${ }^{\mathrm{TM}}$ ) 0-20 mg/L N, Nitrite $\left(\right.$ Nitricol $\left.^{\circledR}\right)$ 0-0.5mg/L N, Ammonia 0-1mg/L N, Phosphate LR 0-4mg/L $\mathrm{PO}_{4}$. Nitrite data are not shown individually but are used in the calculation of dissolved inorganic nitrogen (nitrate+nitrite+ammonia). Total and faecal coliform counts were determined using membrane filtration and incubation on a membrane lauryl sulphate broth saturated pad at $36^{\circ} \mathrm{C}$ and $44^{\circ} \mathrm{C}$ respectively using the ELE Paqualab 50, a portable field kit designed for water quality testing. The ELE Paqualab 50 is comprised of a filtration unit which can be sterilised in the field and two incubation chambers set to the required temperatures. Total coliform counts are not shown here because they were above the threshold for counting in nearly all cases.

\subsection{Vulnerability Assessment}

The vulnerability of a lagoon system can be defined by three key components. These are exposure, sensitivity, and adaptive capacity. A vulnerability assessment should therefore start by defining its objective and choosing the scope and methods accordingly (Ramieri et al, 2011). The objective and scope of this assessment was to identify the vulnerability of the case study lagoons and associated settlements to the impacts of climate change and associated sea level rise. Several methodologies used for the assessment of coastal vulnerability have been identified in the literature. The three most commonly used method are: Indicators (Ramieri et al, 2011), Coastal Vulnerability Index (CVI) (Gorntiz and White, 1992), and GIS or computer-based models (Ramieri et al, 2011).

The indicator-based approach was applied in this study because data gathered from the field present the required evidence/indicators. In addition, this approach allows the evaluation of different aspects related to coastal vulnerability within a consistent assessment context (Ramieri et al, 2011). The approach expresses vulnerability of the coast by a set of independent elements or indicators that characterise key coastal issues (exposure, vulnerability and adaptive capacity) such as coastal lagoon or river inlets, development pressures at the backshore, state of the beach (stable or erosion), impacts of the coastal processes (waves, tides, storm, and longshore transport), previous responses, exposure, sensitivity, risk, and damage cause by continuous or episodic coastal events. These indicators were appraised for each lagoon inlet and the adjoining areas at the backshore up to $1 \mathrm{~km}$ inland. The assessment ranks the lagoons inlet as high, moderate or low vulnerability depending on their exposure to the impacts of climate change and potential risk to life and properties at the backshore. The 
outcomes have been combined into the final summary vulnerability assessment in Table 4.

\subsection{Results}

\subsection{Overview of sampling}

A complete set of results reflecting the water quality measured in the lagoons is shown in Figures 3-4 and Table 5. These results are all point measurements and do not take account of any variations occurring during the tidal cycle, though these would have been small, given the tidal range. The letters ' $S$ ' and ' $J$ ' in all figures refer to the September and January campaigns, respectively. Lagoon numbering from L1 to L8 follows that set out in Table 2, and the letters A to $E$ denote a direction of travel from the sea landwards in all cases.

To allow comparison of these results with international standards, the equivalent levels relating to the European Union (EU) water framework directive for the UK (WFD UK TAG, 2008), the European nitrates directive (Council Directive 91/676/EEC), and European bathing water standards pre 2012 (Council Directive 76/160/EEC) have all been provided with each figure in order to show how the concentrations of nutrients, dissolved oxygen and faecal coliforms in these Ghanaian lagoons compare to standards commonly used in Europe. Direct comparison is difficult because of issues that arise when using transitional and coastal water quality data from the UK to consider standards for lagoons in Ghana given that the ambient temperature of the water is generally higher, and different environmental organisms provide different services to those that apply in the EU case. Ghana relies on WHO water quality guidance (2011) for drinking water quality. There are no local water quality standards or WHO standards for lagoons or coastal waters. This highlights the need for a comprehensive set of parameters that can be applied to waters along the coast of Ghana, given the number of people affected by coastal development.

It must also be noted that these results are spot samples obtained once in the rainy season (September 2015) and once in the dry season (January 2016), and are therefore not a comprehensive picture representing the full annual cycle. They can, however, provide a starting point for assessing the water quality if the data are considered using a multivariate perspective. For example, it is difficult to test any hypotheses using just two measurements of ammonia concentration, but when these are combined with dissolved oxygen and faecal coliform counts we can start to build a picture of the issues that may be affecting these lagoons, such as poor sanitation measures cause by raw or partially treated sewage entering these water bodies. 


\subsection{Water Chemistry}

Figures $\mathbf{3 a}$ and $\mathbf{3 b}$ show nitrate and ammonia concentrations set against common EU standards used in rivers, which are conventionally deemed to have greater concentrations than transitional and coastal waters due to dilution by sea water. Most of the lagoons' nitrate concentrations would be considered to be of some concern in the rainy season while the results obtained from the sites when we revisited them in the dry season showed a decrease below this level. Site data collected over an annual cycle and averaged as suggested in the WFD methodology may well show that the nitrate concentrations obtained are of no serious concern in these lagoons. The total ammonia concentrations are a source of concern, however. Of the eight lagoons sampled in the dry season, five fall into the 'bad' water quality category with all but one of those remaining in that category even if the standards were twice as high. In high concentrations ammonia has a toxic impact on fish and macro-invertebrates, with sewage effluent being a major source of ammonia in rivers, although agricultural sources can also contribute. The concentrations of total ammonia detected in most of the lagoons sampled are likely to have a deleterious influence on their ecology and local fishing industry in particular (found in and around Lagoons 5-7), where the effects of this anthropogenic impact must be felt most keenly.

Another major implication of large nutrient inputs into water bodies is the increased likelihood of eutrophication. In coastal areas this is often measured as dissolved inorganic nitrogen (nitrate + nitrite + total ammonia, known as DIN) and soluble reactive phosphorus (SRP). The EU guidelines for DIN in transitional waters and coastal bodies are lower than the nitrate or ammonia standards that apply in rivers due to the expected dilution factor. Figure 3(c) shows that in all cases the lagoons fell into the 'bad' water quality category for DIN but this is a result of the very high total ammonia concentrations. This large concentration of DIN indicates that these sites are at risk of eutrophication. While we did not analyse for chlorophyll-a when filtering water samples for nutrient analysis, evidence for eutrophication in clogged, green filters was in fact only seen at Lagoons 1-3. This apparent discrepancy may be a result of the relatively low concentrations of SRP (Figure 3(d)) in Lagoons 4-8 in comparison with the high DIN and it is possible that phosphorus is a limiting factor for phytoplankton growth at these sites. Anecdotally the clogged green filters were only seen at Lagoons 1-3 where the SRP was 10-100 times greater than that observed further west. Although SRP concentrations are generally in the good-to-moderate range compared to EU rivers (Figure 3(d)), it might be considered prudent to bring in legislation to maintain these levels now rather than see them increase and bring with them the many problems associated with eutrophication of coastal waters.

Dissolved oxygen concentrations are shown in Figure 4(a) and in most cases range between good and high (EU) status despite temperatures being higher in Ghanaian waters (Table 5) than in waters in northern Europe, which would have the effect of reducing the solubility of the oxygen. A notable exception to this is Lagoon 2 where 
concentrations are very low and heading towards anoxia. The low oxygen and high DIN and SRP concentrations here strongly suggest that eutrophication is occurring. It can be expected that virtually no fish or aquatic macro-invertebrates would be able to survive in these waters for long and if the oxygen concentrations do fall the site could be affected by poor odour due to a shift to anaerobic conditions. This would certainly have an impact on the local users of the water, including cattle farmers and small business owners who may wish to purchase land adjacent to lagoons to build beach resorts, for example.

\subsection{Bacteria}

No faecal coliform data were collected during the initial sampling in September 2015 but these data were collected in January 2016 (Figure 4(b)). Faecal coliform counts in warmer waters should be treated with caution because they tend to be indicative of the presence of bacteria rather than being DNA-specific, but they nevertheless provide a comparative tool for assessing the Lagoons. Lagoon 2 shows a much greater concentration than Lagoons 5 or 7 . The number of colonies in just $1 \mathrm{ml}$ of water in Lagoon 2 was too great to count on a single filter so we can only infer that per $100 \mathrm{ml}$ there would have been in excess of 20,000 counts. This figure is somewhat lower in the sea water outside Lagoon 2 once the water has been diluted by the ocean (Figure 4(b), L2 J A), but within the lagoon these high concentrations together with the high nutrient concentrations and the low dissolved oxygen suggest a particular problem related to (perhaps untreated) sewage discharge in this area.

Samples taken for faecal coliforms from Lagoons 5 and 7 are generally below the threshold that would have been a failure of the bathing waters directive pre 2012 in the EU. These lagoons also have a lower DIN and SRP concentration. These differences may be due the greater flushing they receive from seawater or because they receive less sewage than Lagoon 2, or it may be a result of the combination of these 2 factors.

\subsection{Salinity and Turbidity}

Perhaps unsurprisingly the results shown in Table 5 show a range of values in terms of salinity and turbidity, though the results for temperature and $\mathrm{pH}$ are more predictable and less variable. Lagoon 2 shows a lower salinity in the January deployment than in September, reflecting the dynamic nature of the inlet allowing different degrees of flushing to take place; the inlet was also in a different position in January compared with September. Lagoon 7 is characterised by a higher salinity in January, due to the lower freshwater flow. Results for turbidity in Lagoon 5 and 7 show large differences which may be a result of the activities of fishermen immediately prior to the visit. 


\subsection{Discussion}

\subsection{Understanding the systems and their vulnerability}

We now consider the results described above and comment on what they signify for our understanding of the management of lagoons in particular, and what that then implies for the management of lagoons in developing countries where coordinated coastal development and environmental management may be secondary considerations in comparison with local economic needs. Our results show Ghana lagoons in varying states in terms of water quality. In general, the lagoon water quality is better further to the west, away from the main urban centres, and further away from the capital Accra in particular. Although all our measured data relate to two one-week periods and do not cover an annual cycle, it is still possible to use the collected data to draw some conclusions about the threats to the sustainability of the lagoons, and make some recommendations about their effective long-term management. In many remote coastal communities around the world, the problems of data collection and in particular 'groundtruthing' are clear: many sites are remote and poorly served by infrastructure. Nevertheless we believe that these two periods illustrate some of the features that characterise the use, form, and functioning of lagoons in this part of the world, which can inform the management strategies used, as outlined below.

The outcome of the vulnerability assessment in Table 4 clearly show that factors such as sea level rise, tidal range and wave height were relatively less variable in the case study area and therefore were not the main determinants of the vulnerability of individual lagoons. However, physical variables (elevation, geology, geomorphology and especially erosion and development or economic activity at the backshore) played a major role in the determination of the relative vulnerability. It is key therefore to avoid human intervention and development that have a negative impact on the physical conditions, and it is important to enhance the natural resilience for sustainable adaption of the lagoons and associated ecosystems. It is imperative that vulnerable lands around/near coastal lagoons are not developed in a way that will warrant artificial protection some time in the future (Norcross-Nu'u et al, 2008). The permanently and temporarily closed lagoon inlets (Lagoons 2,6 ) hinder both flood and ebb tidal exchange. This implies that coastal settlements at the sides of these inlets are at risk of flooding from fresh water from the lagoon catchment resulting from high rainfall in the catchment as well as from flooding resulting from tidal and storm surge, which cannot then easily escape. This makes defending the coastal frontage of towns adjacent to lagoons against rising sea levels both economically expensive and technically challenging. 


\subsection{Lagoon Modelling strategies}

In light of the importance both of climate change and other anthropogenic changes related to coastal developments of one sort or another, we now turn to the question of what modelling strategy should be used to inform management strategies to address the whole issue of risk and vulnerability. Modelling allows us to test scenarios, and it is only by doing this that we can answer questions posed by policy makers. Clearly the choice of model depends on the question being asked, but such models are likely to range from the zero-dimensional, where we consider the lagoon as a level pool of water with any hydrological inputs being translated into a uniform lagoon-wide increase in water level depending on plan area, to the fully three-dimensional hydrodynamic. At the same time we must take into account the changes in beach morphology given that these dictate the degree of closure of the breach through which the sea water must pass each tide. It is therefore important to consider the rate of longshore drift, and any other local factors such as the presence of headlands, before undertaking any form of hydrodynamic modelling. Modelling lagoons of this type must therefore be seen as a two stage process, in which we first assess the long term geomorphology before turning to the hydrodynamics. Put simply, however, the recommendation must be that in view of their generally long, thin plan shape and shallow bathymetry, a 1D hydrodynamic model seems the most appropriate. The balance between fresh water flow and sea water inputs causes a longitudinal salinity gradient, which together with the along-channel variations in velocity over the tidal cycle mean that validating and calibrating such a model is a relatively straightforward affair. The higher degree of complexity afforded by 2- and 3-D modelling of these structures implies the need for far more field data, which would be expensive to collect and may not yield much return in terms of a better understanding of the processes involved.

\subsection{Policy formulations}

Based on what we know from these lagoons, it is important to consider the threats and how can we address these in the light of the need for a comprehensive and inclusive management strategy, referring to existing literature. Different adaptation policy options (Nicholls et al, 2007) could be considered for the management of coastal lagoons in Ghana. However, it is important to avoid placing an additional burden of responsibility on future generations by unnecessary pollution of coastal lagoons and development on vulnerable coastal lagoon areas, thereby increasing the number of areas to be artificially protected in the long term (DEFRA, 2001). Present settlements and developments that are located in areas at risk of flooding, coastal erosion and potential submergence might consider accommodation policies or perhaps retreat, depending on the level of risk involved (Walsh et al, 2004). In order to reduce the potential risk of sea level rise to lagoons and integrate an appropriate adaptive response to the most vulnerable areas, there is a need for Ghana to develop a holistic management plan for the coastline similar to UK Shoreline Management Plans (DEFRA, 2006) Ghana could pursue an 
adaptive coastal management plan that seeks to achieve the following key policies outlined after Boatman et al (2008), DEFRA (2006), and Walsh et al. (2004):

- Manage the risks affecting life and properties in vulnerable lagoon areas.

- Protect existing developments that are vulnerable using a baseline analysis of long-term sustainability and the impacts of the physical environment.

- Ensure that adaptation plans and policies comply with the national and international legislations with minimum compromises in respect of the natural environment, navigation, human rights and cultural heritage.

- Implement management policies that allow for future flexibility in response to changes in physical conditions and in socio-economic circumstances at the frontages of vulnerable areas

- Ensure that management plans for any lagoon inlet consider potential impacts on adjoining coastline to reduce any knock on effect

- Encourage continuous monitoring of water quality, and other climatic and physical process that impact on the lagoons.

Furthermore, it is important to highlight the need to educate coastal communities about coastal vulnerability, land use planning and the possible implications of settling in coastal areas subject to flood and erosion risk. Settlements in vulnerable areas should be educated about the potential impacts climate change could have on their lives, properties and local economy. They should be involved in the decision-making processes regarding the planning, development, and implementation of adaptation policies. Accommodation and realignment measures can help to manage risks in the short-to-medium term and such measures should be implemented immediately to reduce any activities that heighten the risks.

Just as in many parts of the world, the importance of managing the shoreline to allow lagoons to flush is of paramount importance. This must include an understanding of longshore drift and coastal defence, and possibly also the contribution from sources further upstream, though in our cases this consideration seems relatively minor. In the case of Lagoon 2, various coastal defence works have caused sediment build up to continue, encouraged by other considerations at the expense of the 'heath' of the lagoon. In Lagoons 5 and 7, the breach is likely to be self-sustaining because the presence of natural headlands and the establishment of a vibrant fishing industry means that there is no way for the beach to build up for sufficiently long to block the channel feeding the lagoon from the sea. 


\subsection{Future Challenges}

For the future, sea level rise and increased storminess will doubtless affect the flushing of these systems. This may be a cause for some optimism, because if the level of flushing increases the anthropogenic pollutants may be diluted, improving the water quality. Conversely if there is a change in the sediment dynamics along the shoreline as a consequence of hydrological change, leading to higher and wider barriers and reduced exchange with the sea, will the 'cleaner' fishing lagoons become more like Lagoon 2 with its potential for eutrophication and accompanying reduction in ecological status?

This study highlights the need for an integrated water quality strategy including standards and enforcement, particularly if the aim is to increase tourism and other revenues and to maintain the fishing revenues that are currently so important in coastal areas whilst allowing the necessary adaption to climate change to take place. There is a further related need to ensure that any discharge consenting process for the outlets from sewage treatment works, for example, takes better account of the local coastal flushing characteristics of the lagoons.

It is fully recognised that our initial synthesis presented here represents something of a 'snapshot' in time and space, and any future research should aim to undertake longer term monitoring, particularly related to the response to the systems following storm events, and their subsequent recovery. A further related avenue of enquiry relates to the impact of coastal defences or coastal development, and the questions this raises about what shoreline or coastal management plans are appropriate, if any, in such dynamic regions. While it is clear that this section of the West African coast has received a fraction of the research attention it deserves in terms of the potential for economic growth and general development, we remain optimistic that the outcomes of this and other similar work can form the basis of drives to maximise its potential benefits to local communities and visitors.

\subsection{Conclusions}

Analysis of data obtained relating to a number of coastal lagoons in Ghana has revealed a mixed picture in terms of the condition of the lagoons and in terms of their vulnerability to climate change. While continued careful monitoring and management is recommended it is suggested that the following points are relevant in view of the long term viability of these structures.

1. Large numbers of small shallow coastal lagoons in various states of pollution are widely used by many different stakeholders and are under threat from climate change. A vulnerability assessment is proposed revealing the need for careful monitoring, management and planning 
2. The health of a lagoon and its continued sustainability for its current users seems related to the amount of flushing that takes place each tide, which in turn depends on a range of coastal sediment transport processes. It is only by understanding the totality of these processes that the appropriate management strategies can be properly identified and implemented.

3. The use of an appropriate modelling strategy is important in understanding how to best manage the lagoons over the coming decades in light of sea level rise and other factors. A 1-D numerical model for each lagoon, accompanied by the proper understanding of longshore and cross-shore sediment modelling, would seem to offer the most useful balance in terms of the capacity for model validation and calibration.

4. Further long-term data are needed to better understand the development of the lagoons under a variety of pressures in comparison with results from other systems from around the world.

It is only through continued refinement to our understanding of such systems that a truly integrated and broad-based approach can be considered that encompasses the effect of different coastal management strategies on local environments and livelihoods. The required approach requires co-operation and active collaboration between the different stakeholders, but the work involved in understanding the necessary strategies will lead to benefits for local people and the regional economy in the long run.

\section{Acknowledgements}

This research project was partially funded by the Research Development Fund at the University of Portsmouth, UK. The authors also wish to thank Dr Kwasi Appeaning Addo from the University of Ghana and Dr Kwabena Barima Antwi from Cape Coast University for their help managing fieldwork and hosting workshop discussions.

\section{References}

Akrasi S A, 2011. Sediment discharges from Ghanaian rivers into the sea. West African Journal of Applied Ecology Vol.18, 1-13

Albarakati A M A, Ahmad F, 2012. Water column conditions in a coastal lagoon near Jeddah, Red Sea, Oceanologia, Vol. 54, 675-685,

Allersma E, Tilmans W M K, 1993. Coastal conditions in West Africa: a review. Ocean \& Coastal Management, 19(3), 199-240. 
Austin M J, Masselink G, McCall R T, Poate T G, 2013. Groundwater dynamics in coastal gravel barriers backed by freshwater lagoons and the potential for saline intrusion: Two cases from the UK, Journal of Marine Systems, 123-124, 19-32,

Bakun A, 1978. Guinea current upwelling. Nature, 271(1), 147-150.

Boateng I, 2009. Development of Integrated Shoreline Management Planning: A Case Study of Keta, Ghana: Proceedings of the International Federation of Surveyors Working Week 2009- Surveyors Key Role in Accelerated Development, TS 4E, Eilat, Israel, 3-8 May.

Boatman, T. Rees, S. Baehr, J. LaDart, J. Drum, R., 2008. A new role for non-structural shoreline management in developing resilient coastal communities. In: Proceedings of the American Society of Civil Engineers Conference: solution to coastal disasters. Hawaii: ASCE, pp. 526-537

Brito A C, Newton A, Tett P, Fernandes T F, 2012. How will shallow coastal lagoons respond to climate change? A modelling investigation, Estuarine, Coastal and Shelf Science, Vol. 112, 98-104,

Carlin J A, Lee G, Dellapenna T M, Laverty P, 2016. Sediment Resuspension by Wind, Waves, and Currents during Meteorological Frontal Passages in a Micro-tidal Lagoon, Estuarine, Coastal and Shelf Science, Available online

Carrasco A R, Ferreira O, Roelvink D, 2015 Coastal lagoons and rising sea level: A review, Earth-Science Reviews, Available online

Chapman P M, 2012. Management of coastal lagoons under climate change, Estuarine, Coastal and Shelf Science, Vol 110, 32-35

Chikita K A, Iwasaka W, Al Mamun A, Ohmori K, Itoh Y, 2012. The role of groundwater outflow in the water cycle of a coastal lagoon sporadically opening to the ocean, Journal of Hydrology, Vols. 464-465, 423-430

Conesa, H M, Jiménez-Cárceles, F J, 2007. The Mar Menor lagoon (SE Spain): A singular natural ecosystem threatened by human activities. Marine Pollution Bulletin, Vol. 54, 839-849

DEFRA (UK Department for Environment Food and Rural Affairs), 2001. Shoreline management plans: further guidance for coastal defence authorities. Retrieved from http://www.defra.gov.uk/environ/fed/pubs/smp.htm

DEFRA (UK Department for Environment Food and Rural Affairs), 2006. Shoreline management plan guidance. Volume 2: procedures. Retrieved from http://www.defra.gov.uk/environ/fcd/guidance/smpguid/volume2.pdf 
Duck R W, Figueiredo da Silva J, 2012. Coastal lagoons and their evolution: A hydromorphological perspective, Estuarine, Coastal and Shelf Science, Vol. 110, 2-14

Dussaillant A, Galdames P, Sun C, 2009. Water level fluctuations in a coastal lagoon: El Yali Ramsar wetland, Chile, Desalination, Vol. 246, 202-214

Entsua-Mensah M, Ofori-Danson P K, Koranteng K A, 2000. Management issues for the sustainable use of lagoon fish resources, p. 24-27. In E.K. Abban, C.M.V. Casal, T.M. Falk and R.S.V Pullin (eds.) Biodiversity and sustainable use of fish in the coastal zone. ICLARM Conf. Proc. 63, 71 p.

Entsua-Mensa, M. 2002. The contribution of coastal lagoons to the continental shelf ecosystem of Ghana. The Gulf of Guinea large marine ecosystem: Elsevier. Science B.V.

Gaertner-Mazouni N, De Wit R, 2012. Exploring new issues for coastal lagoons monitoring and management, Estuarine, Coastal and Shelf Science, Vol. 114, 1-6

Ghana statistical Services, 2015. Ghana statistical Services: statistics for development and progress. Retrieved from: http://www.statsghana.gov.gh/docfiles/GDP/GDP2015/ AnnualGDP2014_template_2014Q4_April\%202015\%20edition_web.pdf

Gornitz, V. and White, T.W. 1992. A Coastal Hazards Database for the U.S. West Coast: ORNL/CDIAC-81, NDP-043C, Oak Ridge National Laboratory, Oak Ridge, Tennessee.

Haghani S, Leroy S A G, 2016. Differential impact of long-shore currents on coastal geomorphology development in the context of rapid sea level changes: The case of the Old Sefidrud (Caspian Sea), Quaternary International, Available online

Henin C, Hisard P, Piton B, 1986. Observations hydrologiques dans l'Ocean Atlantique Equatorial (Vol. 1). Paris: OSTROM Editions.

IPCC, 2014. Climate Change: Impacts, Adaptation, and Vulnerability. Part A: Global and Sectoral Aspects. Contribution of Working Group II to the Fifth Assessment Report of the Intergovernmental Panel on Climate Change. Cambridge: Cambridge University Press.

Jewell S A, Walker D J, Fortunato A B, 2012. Tidal asymmetry in a coastal lagoon subject to a mixed tidal regime, Geomorphology, Vol. 138, 171-180,

Kjerfve, B., 1986. Comparative oceanography of coastal lagoons. In: Wolfe, D.A. (Ed.), Estuarine Variability. Academic Press, New York, 63-81

Kjerfve B, 1994. Coastal lagoon processes. Elsevier, Amsterdam, The Netherlands. 
La Jeunesse I, Cirelli C, Sellami H, Aubin D, Deidda R, Baghdadi N, 2015. Is the governance of the Thau coastal lagoon ready to face climate change impacts?, Ocean \& Coastal Management, Vol. 118, Part B, 234-246

Mitchell S B, Burgess H M, Pope D J, Theodoridou A, 2008. Field studies of velocity, salinity and suspended solids concentration in a shallow tidal channel near tidal flap gates. Estuarine, Coastal and Shelf Science, Vol. 78, 385-395

Moreno I M, Ávila A, Losada M A, 2010. Morphodynamics of intermittent coastal lagoons in Southern Spain: Zahara de los Atunes, Geomorphology, Vol. 121, 305-316

Nicholls, R.J, Wong, P.P. Burket, V.R. Codignotto, J, Hay, J.E. McLean, R.F. et al, 2007. Coastal systems and lowlying areas. In: Parry ML, Canziani OF, Palutikof JP, van der Linden PJ, Hanson CE (eds) Climate change 2007: impacts, adaptation and vulnerability. Cambridge University Press, Cambridge, pp 315-356

Norcross-Nu'u, Z., Fletcher, C., Barbee, M., Genz, A. \& Romine, B. 2008. Bringing sea-level rise into long range planning consideration on Maui, Hawaii. In Proceedings of the American Society of Civil Engineers Conference: Solution to Coastal Disasters (pp.107-116). Hawaii: ASCE

Ozturk D, Sesli F A, 2015. Shoreline change analysis of the Kizilirmak Lagoon Series, Ocean \& Coastal Management, Vol. 118, Part B, 290-308

Pasquini A I, Niencheski L F H, Depetris P J, 2013. The ENSO signature and other hydrological characteristics in Patos and adjacent coastal lagoons, south-eastern Brazil, Estuarine, Coastal and Shelf Science, Vol. 111, 139-146,

Ramieri, E. Hartley, A. Barbanti, A. Duarte Santos, F. Gomes, A. Hilden, M. Laihonen, P. Marinova, N. \& Santini, M. (2011). Methods for assessing coastal vulnerability to climate change. European Topic Centre on Climate Change Impacts, Vulnerability and Adaptation (ETC CCA) Technical Paper 1/2011: European Environment Agency.

Roselli L, Cañedo-Argüelles M, Costa Goela P, Cristina S, Rieradevall M, D'Adamo R, Newton A, 2013. Do physiography and hydrology determine the physico-chemical properties and trophic status of coastal lagoons? A comparative approach, Estuarine, Coastal and Shelf Science, Vol 117, p-p??

Serrano D, Ramírez-Félix E, Valle-Levinson A, 2013. Tidal hydrodynamics in a two-inlet coastal lagoon in the Gulf of California, Continental Shelf Research, Vol. 63, 1-12

Stieglitz T C, van Beek P, Souhaut M, Cook P G, 2013. Karstic groundwater discharge and seawater recirculation through sediments in shallow coastal Mediterranean lagoons, determined from water, salt and radon budgets, Marine Chemistry, Vol. 156, 73-84 
Tenorio-Fernandez L, Gomez-Valdes J, Marino-Tapia I, Enriquez C, Valle-Levinson A, Parra S M, 2016. Tidal dynamics in a frictionally dominated tropical lagoon, Continental Shelf Research, Vol. 114, 16-28

UK Technical Advisory Group on the Water Framework Directive (WFD UK TAG), 2008, UK environmental standards and conditions (phase 2)

Water Resources Commission, 2009. Ankobra River Basin: Integrated Water Resources Management Plan. Accra, pp.64

Webster I T, 2010. The hydrodynamics and salinity regime of a coastal lagoon - The Coorong, Australia - Seasonal to multi-decadal timescales, Estuarine, Coastal and Shelf Science, Vol. 90, 264-274,

Walsh, K. J. E., Betts, H., Church, J., Pittock, A. B., McInnes, K. L., Jackett, D. R., et al., 2004. Using sea level rise projections for urban planning in Australia. Journal of Coastal Research, 20(2), 586-598

Wellens-Mensah J, Armah A K, Amlalo D S, Tetteh K, 2002. Development and protection of the coastal and marine environment in Sub-Saharan Africa: Ghana. In National report phase 1: integrated problem analysis. Nairobi: UNEP.

WHO, 2011. Guidelines for Drinking-Water Quality. Geneva: World Health Organization, 2011.

\section{Figures}

Figure 1 Map showing study area

Figure 2. Lagoon examples showing typical 'open' and 'closed' lagoons

Figure 3 Lagoon concentrations of (a) dissolved total ammonia $(\mathrm{mg} / \mathrm{L} \mathrm{N})$ in September (light grey, S) and January (dark grey, J) shown with the WFD (UK) standards for rivers: high (0.3), good (0.6), moderate (1.1) and poor (2.5). Concentrations need to be below that threshold to achieve that quality status and anything above 'poor' is defined as 'bad' in quality; (b) dissolved nitrate $(\mathrm{mg} / \mathrm{L} \mathrm{N}$ ) with the UK nitrates directive standards for rivers: polluted (50) and of concern (25); (c) dissolved inorganic nitrogen (mg/L N) with the WFD standards for coastal and transitional waters: high (0.28), good (0.42), moderate (0.63) and poor (0.95); (d) soluble reactive phosphorus (mg/L P) with the WFD standards for coastal and transitional waters: high (0.05), good (0.12), moderate (0.25) and poor (1.0).

Figure 4 Lagoon concentrations of (a) dissolved oxygen (mg/L) in September (light grey, S) and January (dark grey, J) with the WFD (UK) standards for coastal and transitional 
waters: high (0.05), good (0.12), moderate (0.25) and poor (1.0). Note these standards are reversed from the nutrient standards in that concentrations need to be above that threshold to achieve that quality status and anything below 'poor' is defined as 'bad' in quality; (b) counts for faecal coliforms per 100ml with the pre-2012 UK bathing water standards fail $(>2000)$ and higher $(<100)$. There are no data available for the lagoons in September and L2 J B-E gave counts above 20,000 per 100ml.

Figure 5 Arial photographs of Lagoons 1-8. Position of the entrance is as shown in each case

\section{Tables}

Table 1. Recent literature related to understanding and management of lagoon systems worldwide

Table 2. List of lagoons sampled with locations

Table 3. Tidal characteristics of ports in Ghana. After Wellens-Mensah et al, (2002) and Allersma and Tilmans (1993)

Table 4. Vulnerability assessment undertaken for all lagoons studied

Table 5. Salinity, $\mathrm{pH}$ and turbidity, sites refer to lagoon numbers (see Figure 1), with the letters A-E from the sea to the landward end 

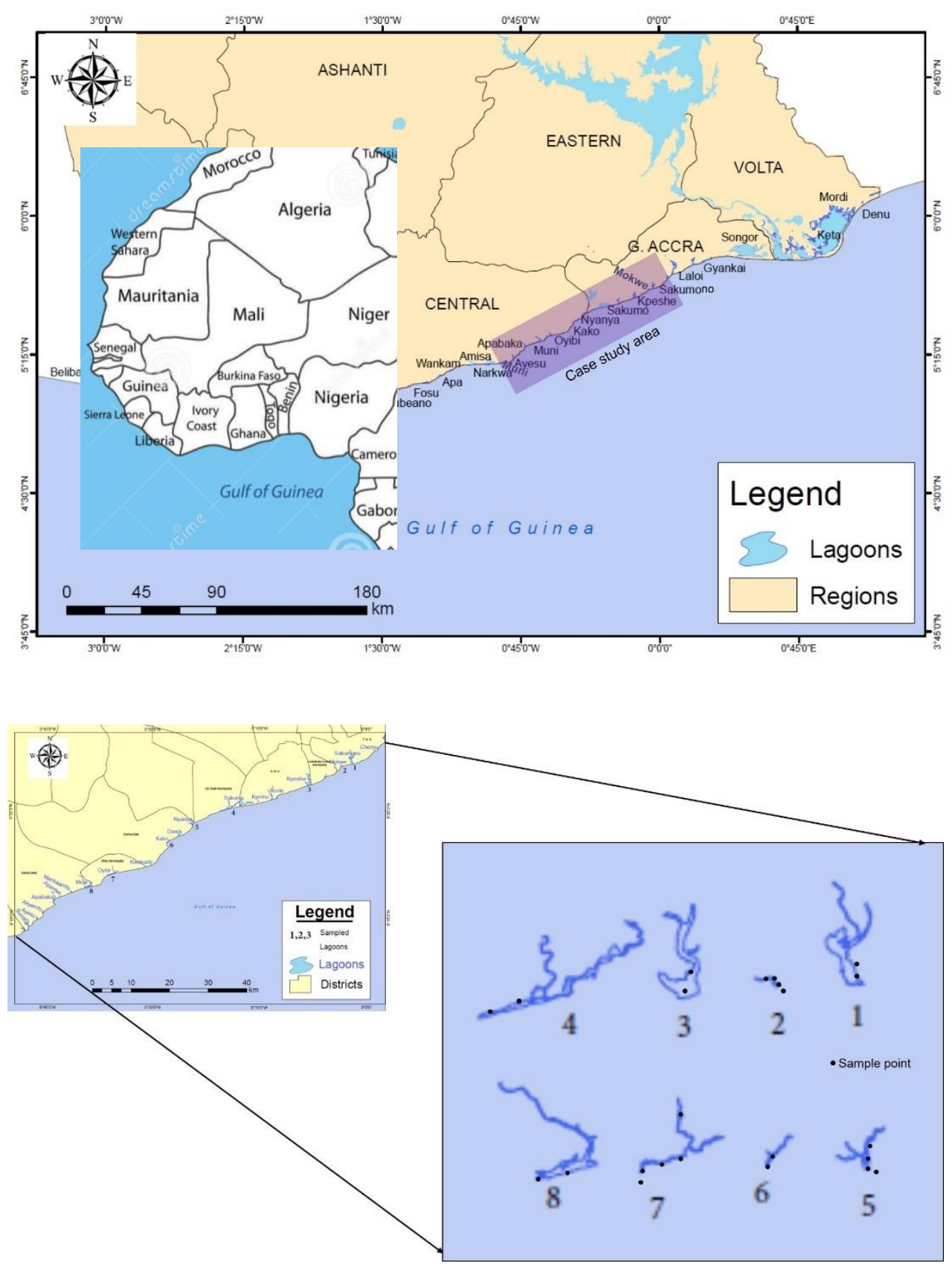

Figure 1 


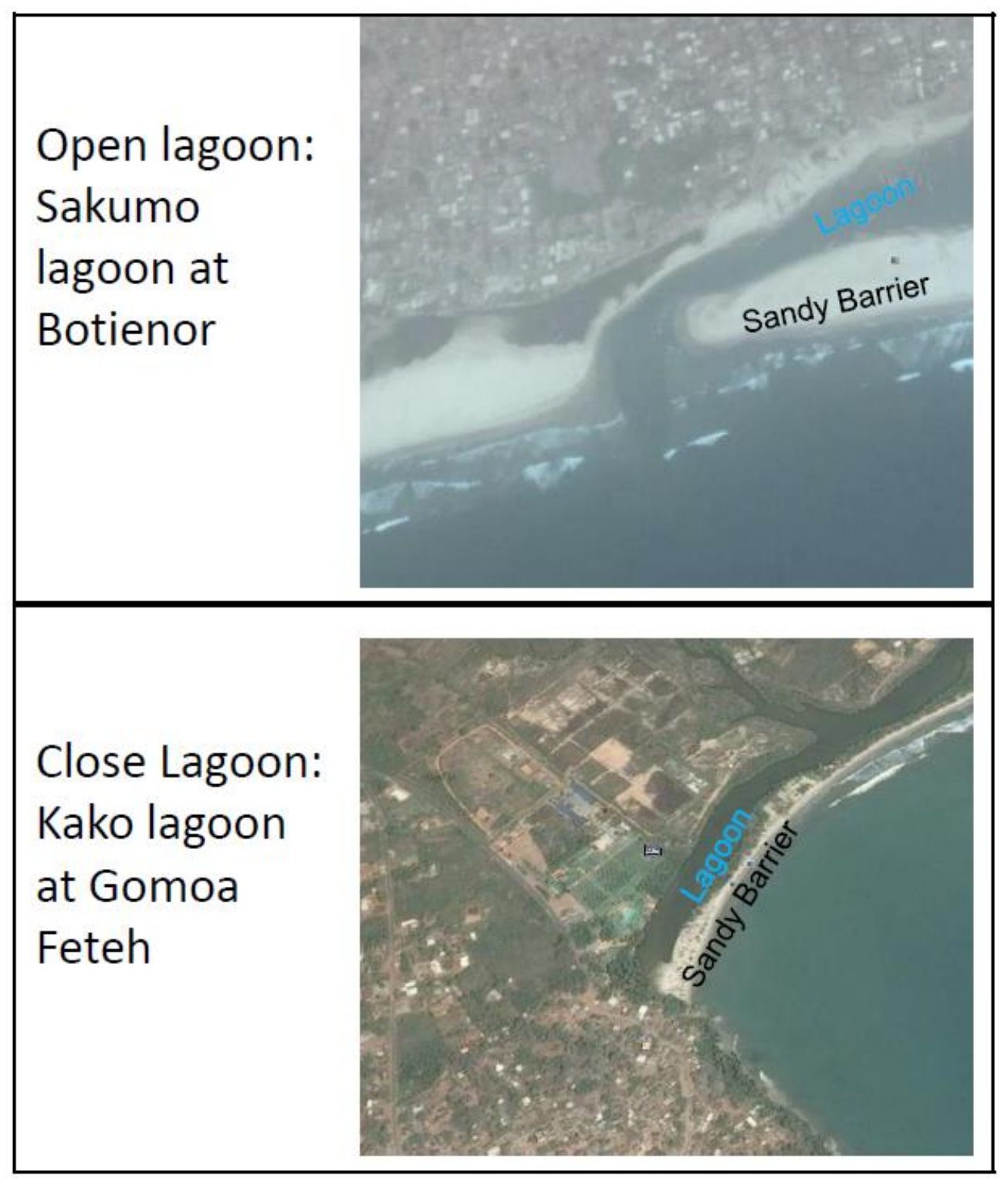

Figure 2 

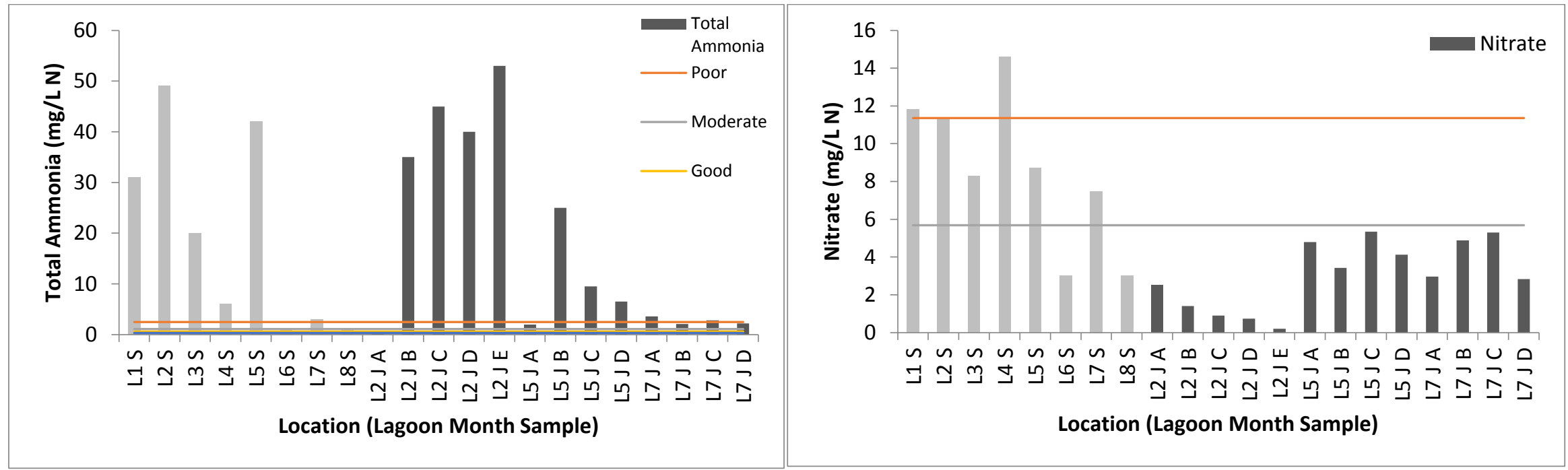

(c)

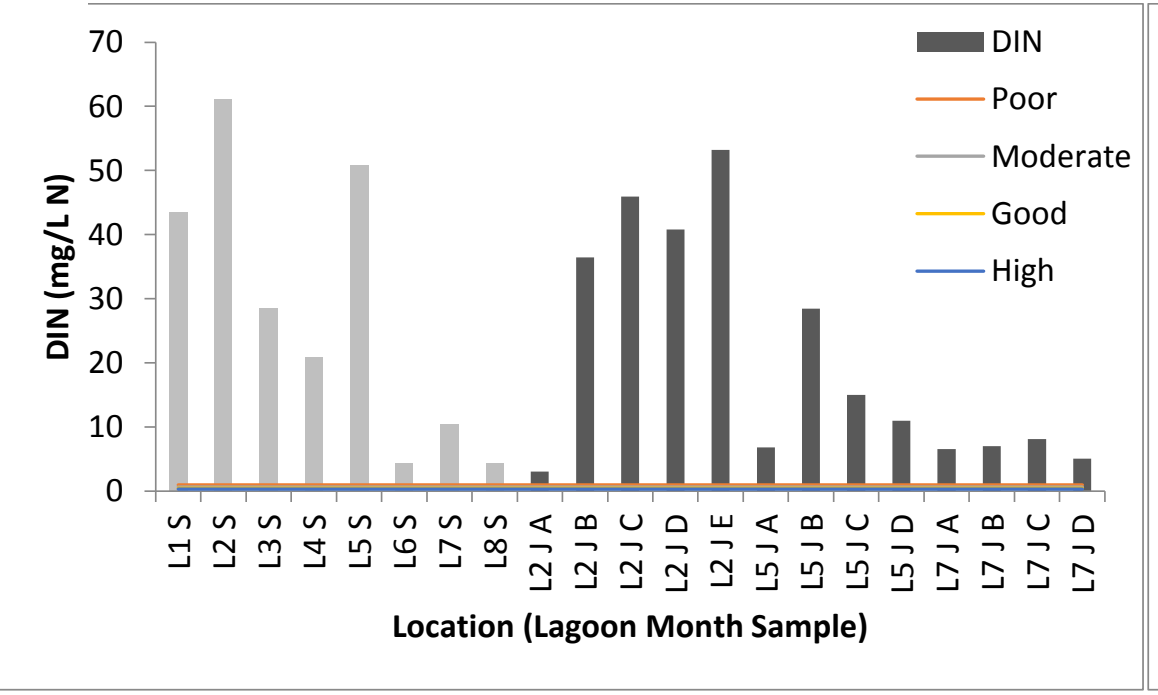

(d)

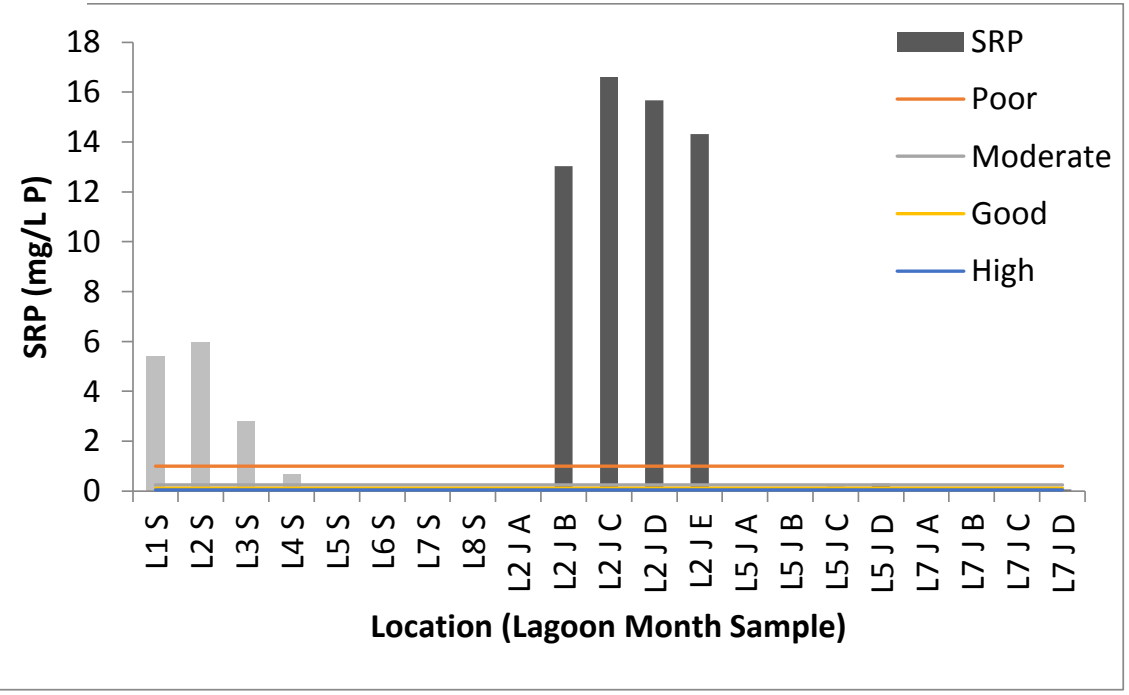

Figure 3 
(a)

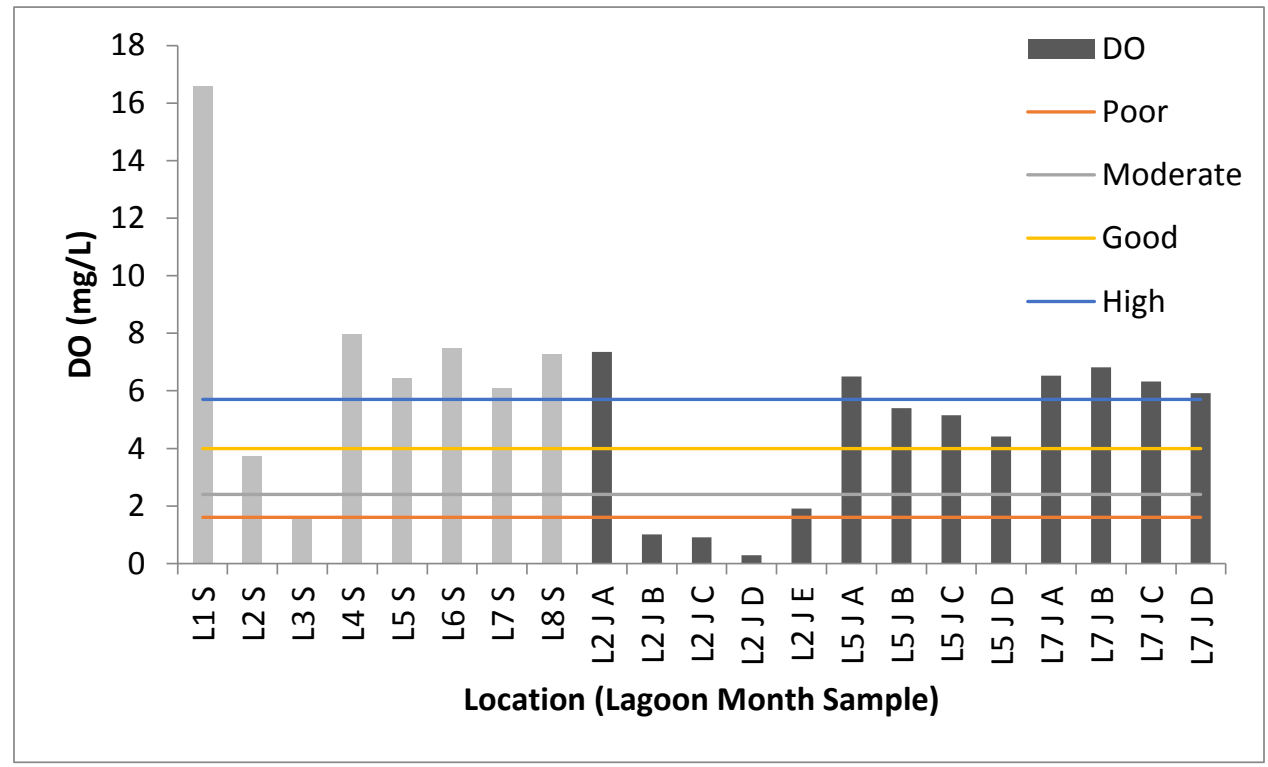

(b)

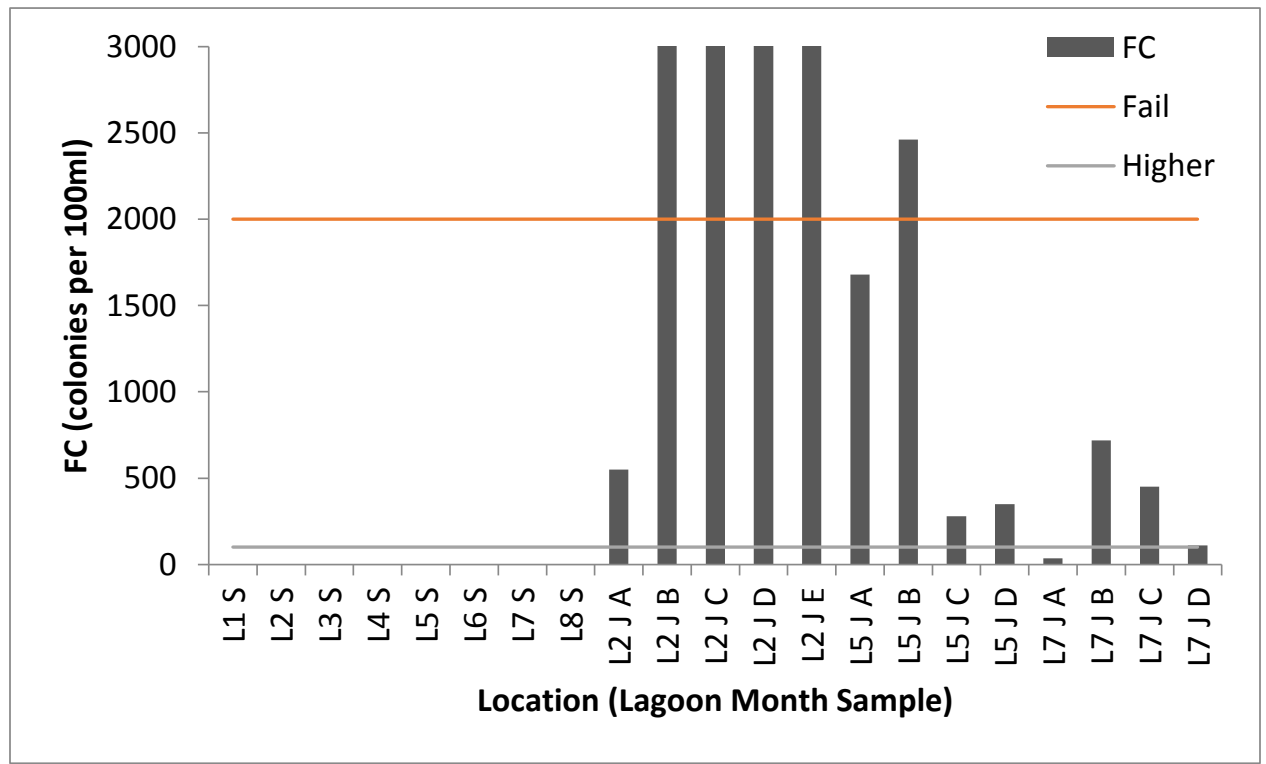

Figure 4 


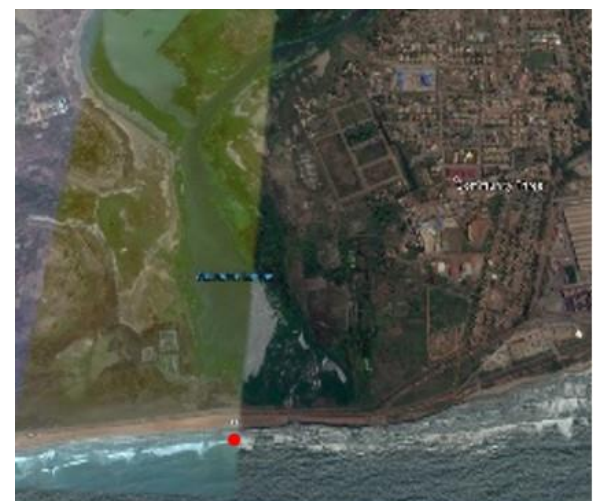

1 Sakumono

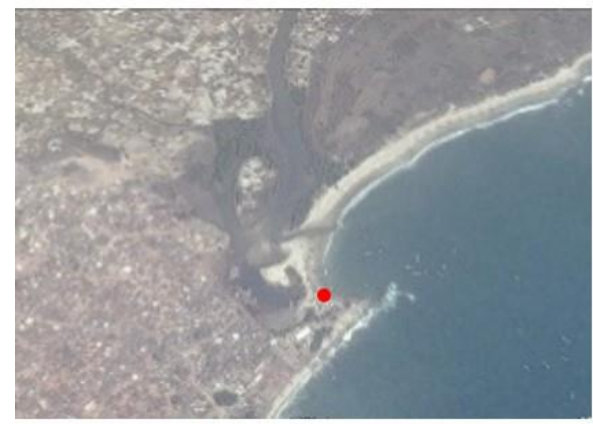

5 Nyanya

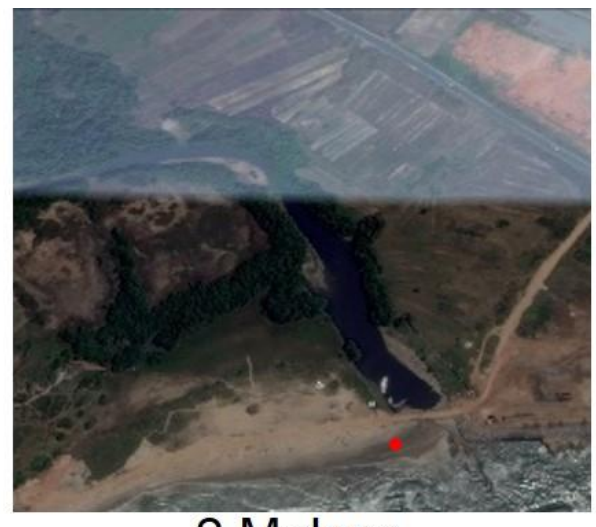

2 Mokwe

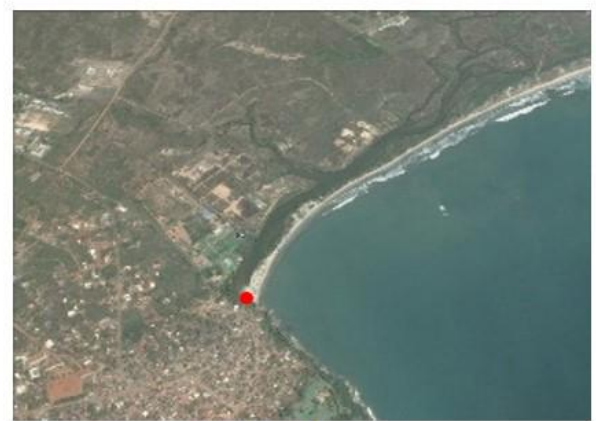

6 Kako

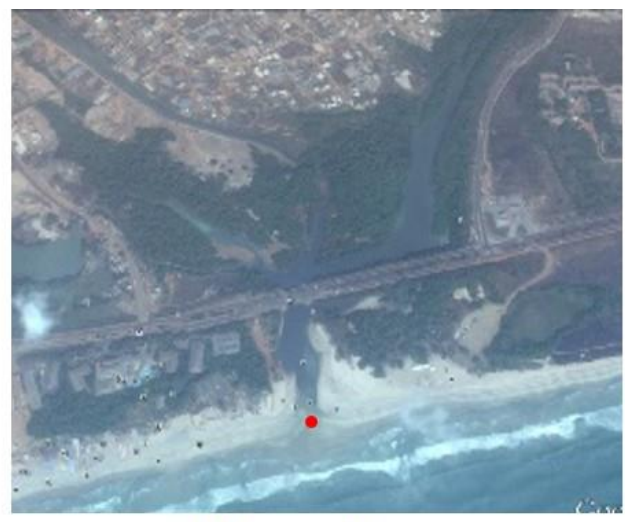

3 Kpeshie

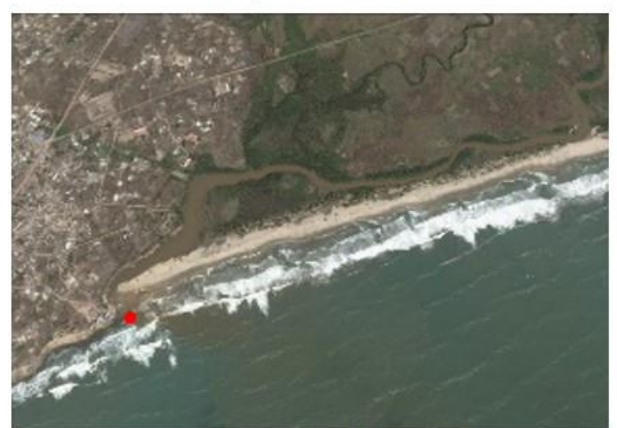

7 Oyibi

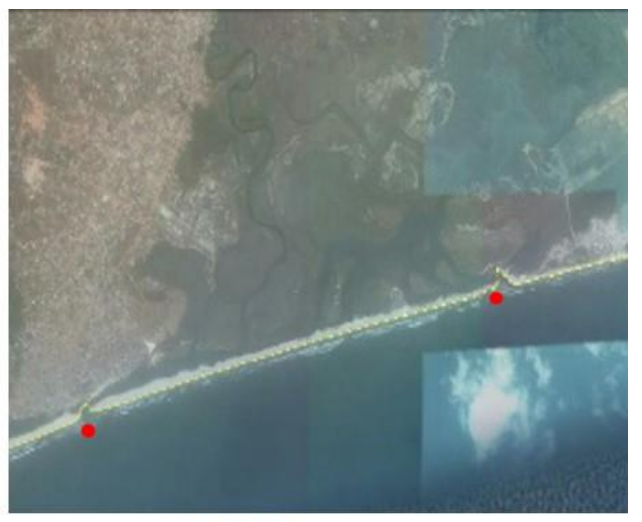

4 Sakumo

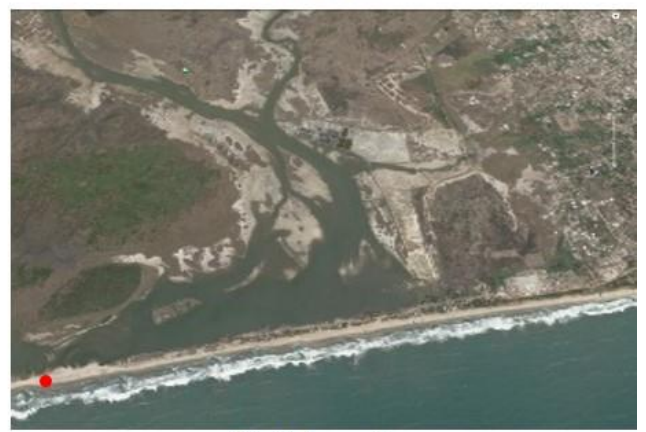

8 Muni

\section{- Inlet}

Figure 5 


\begin{tabular}{|c|c|c|c|}
\hline Authors & Location & Main process of interest & Date \\
\hline Chikita et al & Japan & groundwater & 2012 \\
\hline Albarakati \& Ahmad & Saudi Arabia & Water quality & 2012 \\
\hline Moreno et al & Spain & morphodynamics & 2010 \\
\hline Jewell et al & Australia & Tidal asymmetry & 2012 \\
\hline Stieglitz et al & France & groundwater & 2013 \\
\hline Dussaillant et al & Chile & Water level changes & 2009 \\
\hline Serrano et al & USA & Tidal hydraulics & 2013 \\
\hline Duck \& Figueiredo da Silva & Portugal & Geomorphology & 2012 \\
\hline Pasquini et al & Brazil & ENSO signatures & 2013 \\
\hline Austin et al & UK & groundwater & 2013 \\
\hline Webster & Australia & hydrodynamics & 2010 \\
\hline Carlin et al & USA & Sediment resuspension & 2016 \\
\hline Haghani \& Leroy & Iran & geomorphology & 2016 \\
\hline Ozturk \& Sesli & Turkey & geomorphology & 2015 \\
\hline Tenorio-Fernandez et al & Mexico & Tidal dynamics & 2016 \\
\hline Chapman & Various & Climate change & 2010 \\
\hline
\end{tabular}

Table 1 


\begin{tabular}{|c|c|c|c|c|c|}
\hline Number & Name & Catchment $\mathbf{( k m}^{\mathbf{2}} \mathbf{)}$ & Type & Latitude & Longitude \\
\hline 1 & $\begin{array}{c}\text { Sakumono } \\
\text { Lagoon }\end{array}$ & 77 & $\begin{array}{c}\text { Artificially } \\
\text { restricted }\end{array}$ & 5.616667 & -.033333 \\
\hline 2 & Mokwe Lagoon & 13 & closed & 5.616667 & -.05 \\
\hline 3 & Kpeshie Lagoon & 37 & Open & 5.566667 & -.133333 \\
\hline 4 & Sakumo Lagoon & 2,550 & open & 5.516667 & -.316667 \\
\hline 5 & Nyanya Lagoon & 25 & open & 5.466667 & -.4 \\
\hline 6 & Kako Lagoon & 30 & closed & 5.416667 & -.466667 \\
\hline 7 & Oyibi Lagoon & 1,700 & open & 5.35 & -.583333 \\
\hline 8 & Muni Lagoon & 10 & open & 5.333333 & -.633333 \\
\hline
\end{tabular}

Table 2 


\begin{tabular}{|c|c|c|c|c|}
\hline Location & Neap & Mean & Spring & Phase \\
\hline Takoradi & $0.58 \mathrm{~m}$ & $0.90 \mathrm{~m}$ & $1.22 \mathrm{~m}$ & $107^{\circ}$ \\
\hline Accra & $0.62 \mathrm{~m}$ & $0.94 \mathrm{~m}$ & $1.26 \mathrm{~m}$ & $107^{\circ}$ \\
\hline Tema & $0.64 \mathrm{~m}$ & $0.96 \mathrm{~m}$ & $1.28 \mathrm{~m}$ & $107^{\circ}$ \\
\hline Lome & $0.68 \mathrm{~m}$ & $1.00 \mathrm{~m}$ & $1.32 \mathrm{~m}$ & $108^{\circ}$ \\
\hline
\end{tabular}

Table 3 


\begin{tabular}{|c|c|c|c|c|}
\hline Lagoons & Physical condition & Climate change impacts & Risk, exposure & Vulnerability \\
\hline 1 Sakumono & $\begin{array}{l}\text { Geomorphology: lagoon } 1 \text { is an } \\
\text { artificially restricted inlet which } \\
\text { experiences continuous forcing by the } \\
\text { sea to open the inlet. Lagoon } 2 \text { and } 6 \text { are } \\
\text { closed lagoons, but lagoon } 2 \text { had virtually } \\
\text { no opening at the time of sample due to } \\
\text { the recent sea defence project at the } \\
\text { site. The rest of the lagoons are open } \\
\text { (Table } 2 \text { ). With the exception of Lagoon } 1 \\
\text { which has lost its beach as a result of } \\
\text { about } 2 \text { km of coastal defence on both } \\
\text { sides of the inlet, all the lagoons have } \\
\text { sediment stores in a form of a beach or } \\
\text { barrier (Figure } 5 \text { ). } \\
\text { Geology: all eight inlets contain sand, silt } \\
\text { and clay. However, Lagoons } 2,5,6 \text { and } 7 \\
\text { have eroding limestone outcrops either } \\
\text { in the surf zone or on the western side of } \\
\text { the inlet (Figure } 5 \text { ). } \\
\text { Coastal elevation: all the inlets in the } \\
\text { case study area have elevations ranging } \\
\text { from } 0-5 \mathrm{~m} \text { above sea level. However, } \\
\text { Lagoons } 7,6 \text { and } 5 \text { have high elevation at } \\
\text { the western side of their backshore } \\
\text { (Figure } 5 \text { ). } \\
\text { Coastal erosion/accretion: Erosion along } \\
\text { the shores of the case study area ranges } \\
\text { from } 0.4 \mathrm{~m} \text { to } 5.5 \mathrm{~m} \text { per year, with an } \\
\text { average } 2.7 \mathrm{~m} / \text { year across all the case } \\
\text { study areas (Boateng, } 2012 \text { ). Lagoon } 1 \\
\text { and } 2 \text { have recently experienced higher } \\
\text { erosion than the others, however, the } \\
\text { two inlets have recently been defended. }\end{array}$ & 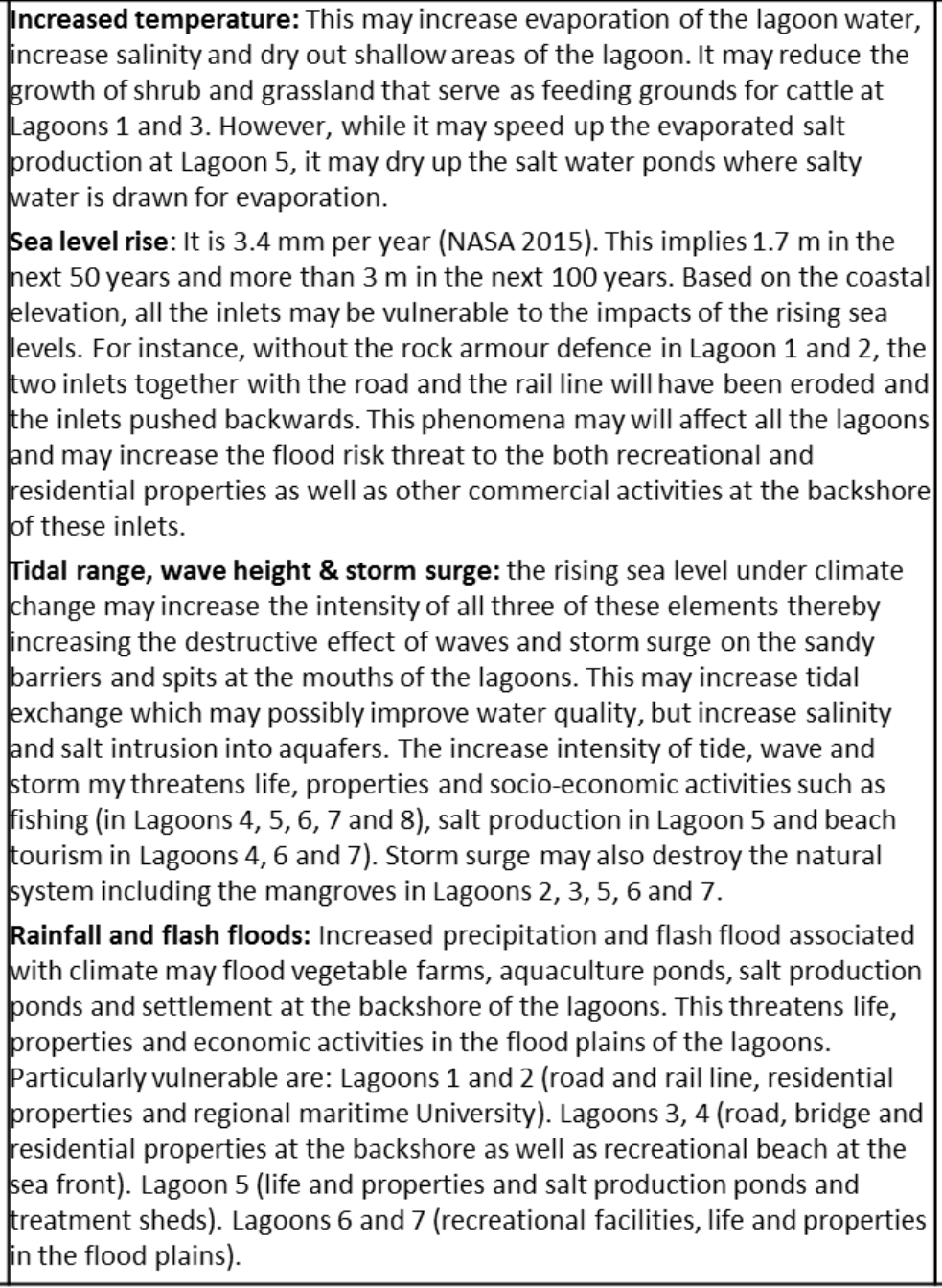 & $\begin{array}{l}\text { All the lagoons are exposed to } \\
\text { the impacts of climate change } \\
\text { outlined in column } 3 \text { and they } \\
\text { are already experiencing the } \\
\text { impact of some of these effects. } \\
\text { However, the/impacts or effects } \\
\text { vary from one lagoon to } \\
\text { another. It has been identified } \\
\text { from our field campaign that all } \\
\text { the lagoons are at risk from the } \\
\text { threat of both human } \\
\text { development and climate } \\
\text { change impacts. Protected } \\
\text { wetland (Lagoons } 1,4 \text { and } 8 \text { ), } \\
\text { residential properties, road and } \\
\text { rail line, recreational facilities, } \\
\text { aquaculture, salt production, } \\
\text { fishing villages, mangroves, } \\
\text { barriers, spits bars and beaches } \\
\text { of the sampled lagoons are } \\
\text { expose to the risk climate } \\
\text { change induced flooding, } \\
\text { erosion and in some instances } \\
\text { submergence of the coastal } \\
\text { frontages due to their low } \\
\text { elevation. The shoreline may be } \\
\text { exposed to increased erosion } \\
\text { thereby moving the present } \\
\text { inlet positions landwards (Figure } \\
5 \text { ) } \\
\text { However, the water quality may } \\
\text { improve as result of increase } \\
\text { tidal exchange and freshwater } \\
\text { flushing, and possible opening of } \\
\text { closed lagoons and widening of } \\
\text { the inlets }\end{array}$ & $\begin{array}{l}\text { Vulnerability of the lagoons } \\
\text { were ranked from high, } \\
\text { moderate and low depending of } \\
\text { the level of exposure to climate } \\
\text { change impact on column } 3 \text { and } \\
\text { the risk to life, properties, } \\
\text { economic activities } \\
\text { infrastructure and the natural } \\
\text { systems both at the inlet and at } \\
\text { the backshore. Lagoons 1, 2, } 3 \\
\text { and } 4 \text { and have high } \\
\text { vulnerability due to their low } \\
\text { elevation and high risk to } \\
\text { significant infrastructure, life } \\
\text { and properties at the backshore. } \\
\text { Lagoons } 5,7 \text { and } 8 \text { have } \\
\text { moderate vulnerability. This is } \\
\text { because developments at the } \\
\text { backshore are located at a } \\
\text { relatively high elevation to the } \\
\text { west (Lagoon } 5 \text { and } 7 \text { ) and to } \\
\text { the east (lagoon } 8 \text { ) (Figure 5). } \\
\text { The natural systems and salt } \\
\text { production which may be } \\
\text { threatened have resilience and } \\
\text { could adapt to the impacts. } \\
\text { Lagoon } 6 \text { was identified to have } \\
\text { a low vulnerability because all } \\
\text { the settlements at the } \\
\text { backshore are located on top of } \\
\text { a high cliff on the western side } \\
\text { of the inlet (Figure 5). The } \\
\text { undeveloped land on the } \\
\text { eastern side of the inlet will } \\
\text { allow migration of the barrier } \\
\text { landwards (Figure 5). }\end{array}$ \\
\hline
\end{tabular}

Table 4 


\begin{tabular}{|c|c|c|c|c|c|}
\hline Site & date & $\begin{array}{c}\text { Temperature } \\
\left({ }^{\circ} \mathbf{C}\right)\end{array}$ & Salinity & pH & $\begin{array}{c}\text { Turbidity } \\
\text { (NTU) }\end{array}$ \\
\hline L1 S & 14 Sep & 29.7 & 2.1 & 8.2 & 34.9 \\
\hline L2 S & 14 Sep & 29.9 & 10.6 & 7.5 & 658.6 \\
\hline L3 S & 15 Sep & 24.4 & 32.6 & 7.1 & 8.6 \\
\hline L4 S & 15 Sep & 26.7 & 36.3 & 7.8 & 8.8 \\
\hline L5 S & 17 Sep & 24.4 & 36.6 & 7.7 & 20.2 \\
\hline L6 S & 17 Sep & 28.4 & 22.7 & 7.8 & 7.1 \\
\hline L7 S & 18 Sep & 26.5 & 6.8 & 7.5 & 10.6 \\
\hline L8 S & 18 Sep & 28.4 & 38.4 & 7.8 & 77.3 \\
\hline L2 J A & 25 Jan & 25.9 & 36.8 & 8.1 & 12.3 \\
\hline L2 J B & 25 Jan & 27.1 & 3.4 & 8.0 & 55.5 \\
\hline L2 J C & 25 Jan & 27.2 & 2.1 & 7.8 & 50.3 \\
\hline L2 J D & 25 Jan & 24.7 & 3.7 & 7.4 & 51.5 \\
\hline L2 J E & 25 Jan & 26.3 & 2.4 & 7.5 & 34.5 \\
\hline L5 J A & 26 Jan & 26.8 & 36.0 & 7.9 & 396.8 \\
\hline L5 J B & 26 Jan & 27.2 & 35.3 & 7.9 & 965.2 \\
\hline L5 J C & 26 Jan & 28.3 & 29.3 & 7.8 & 13.6 \\
\hline L5 J D & 26 Jan & 27.5 & 27.2 & 7.9 & 41.2 \\
\hline L7 J A & 27 Jan & 27.9 & 35.9 & 7.8 & 308.5 \\
\hline L7 J B & 27 Jan & 27.7 & 28.9 & 7.9 & 12.7 \\
\hline L7 J C & 27 Jan & 28.8 & 34.0 & 7.7 & 7.9 \\
\hline L7 J D & 27 Jan & 28.6 & 32.4 & 7.4 & 11.5 \\
\hline & & & & & \\
\hline
\end{tabular}

Table 5 